AFRICAN

\title{
South Korea's changing political environment and the impact on its Africa policy*
}

\author{
by Yejoo Kim \\ Centre for Chinese Studies \\ Stellenbosch University
}

\begin{abstract}
While political and economic self-interest retains its primacy in South Korea's foreign policy towards Africa, recent domestic constraints have negatively affected its Africa policy. This article sheds light on the subtle differences between Roh and Lee's stances towards Africa on the one hand and that of Park on the other hand; whilst further looking at the origin of those differences by examining the political environment of the current administration. The deterioration of inter-Korean relations has led to South Korea's returning to a foreign policy in which security is primary. Simultaneously, resource diplomacy has faced growing criticism from the public and has lost its legitimacy as a basis for engagement with the continent. These two processes have had an impact on the re-orientation of South Korea's foreign policy towards Africa. Africa has, again, been placed at the periphery of South Korea's foreign policy.
\end{abstract}

* This work was supported by Seed Program for Korean Studies through the Ministry of Education of Republic of Korea and Korean Studies Promotion Service of The Academy of Korean Studies (AKS-2016-INC-2230007). 


\section{Introduction}

Political and economic self-interest retains its primacy in South Korea's foreign policy towards Africa. South Korea's successful transformation from a recipient of aid to a donor, coupled with its seeking a middle-power role, have largely contributed to the foundation for the sought after relationships (Choi et al., 2014). At the same time, mercantilism, driven by a desire to obtain raw materials for energy supply and new markets, drove this engagement. Consequently, since the mid-2000s, the government has made some progress with institutionalising its links with the continent.

In particular, former presidents, Roh Moo-hyun (2003-2008) and Lee Myung-bak (2008-2013), have actively forged connections with a number of countries in Africa. Roh Moo-hyun formalised the relationship with Africa by making state visits to Egypt, Algeria and Nigeria in March 2006. And it was the first time a head of state had visited since 1982. ${ }^{1}$ Since Roh's state visits, the First Korea-Africa Forum was held to formulate a roadmap for strengthening cooperation with Africa in November 2006. South Korea's official development assistance (ODA) towards Africa has increased from US\$ 82.57 million in 2008 to US\$ 260 million in 2013 (ODA Korea, 2016). Lee Myung-bak promoted the relationship more vigorously by incorporating African diplomacy as one of the major goals of his foreign policies in 2010 (Cho, 2010). This also resulted in Lee's state visits to South Africa, the Democratic Republic of Congo (DRC) and Ethiopia in 2011. The current President, Park Geunhye (2013 to the present), inherited this tradition and completed her state visits to Ethiopia, Uganda and Kenya in May 2016.

Under the different administrations from Roh to Park, a number of high-level official visits and exchanges have become a means for developing the relationship and were all resource-oriented. This became clear at a time of turmoil in the Middle East, in particular the Iraq War (2003). South Korea's heavy reliance on the Middle East for its oil supplies has been a major concern from the early 2000s, resulting in energy security being the underlying principle of the whole edifice of South Korea's resource diplomacy. 


\section{AFRICAN \\ EAST-ASIAN \\ AFFAIRS

At the same time, its middle-power aspirations intersected with its new "national role" in the international community and this has become an integral part of South Korea's foreign policy towards Africa. Middle-powerism has become a prominent feature of South Korea's foreign policy since the 1990s (Robertson, 2013). South Korea has actively engaged in "multi-lateral organisations and alliances to achieve foreign policy goals" (Hey, 2003: 4). One of the recent examples is the creation of MIKTA (Mexico, Indonesia, South Korea, Turkey and Australia), South Korea and other member countries, so-called emerging powers, hoped that this grouping will become a useful platform to increase their clout. With regard to the African continent, the South Korean government wishes to become a game changer as there has been competition among traditional and emerging partners for influence and relevance. $^{2}$

While these approaches once laid the framework for understanding South Korea's foreign policy initiatives and the future course of action, this article would like to shift the analytic attention from this push-pull logic of the relationship. Instead, this research focuses on understudied underlying aspects which also play a role in shaping South Korea's foreign policy towards Africa by incorporating South Korea's domestic situation and regional challenges with regard to its Africa policy.

When looking into Park's foreign policy towards Africa in particular, there have been indications of change in the relationship, despite the continuity. While the analysis of South Korea's pursuit of national interest became the dominant discourse in the literature, relatively little critical analysis has focused on other aspects that have, perhaps equally and substantially, influenced the direction of South Korea's foreign policy. Seemingly, the recurrent visits by South Korean leaders have shown the country's interest in continuing its relationships with Africa (Kang, 2016). However, Park's approach to Africa differs from that of the former administrations' explicit resource-seeking behaviour. This article sheds light on the subtle differences between Roh and Lee's stances towards Africa on the one hand and that of Park on the other hand, as well as on the origin of those differences by examining the political environment of the current administration. 
This article is organised as follows: Firstly, South Korea's underlying constraints on its foreign policy towards Africa is discussed. Secondly, a general overview of South Korea's engagement with Africa focusing on its pursuit of national interests is provided. This is followed by a discussion focusing on two challenges that South Korea faces, namely, its security challenge vis á vis North Korea, as well as the mounting criticism of resource diplomacy and their implications for South Korea's foreign policy towards Africa.

\section{Underlying constraints on South Korea's foreign policy towards Africa}

The existing body of literature exhibits various aspects that curtail small or middle powers' foreign policy options and goals (Vital, 1971 in Hey, 2003). South Korea's foreign relations are largely shaped by its geo-political situation, the confrontation with North Korea, and limited to the key security stakeholders such as the US, China and Japan. Under the circumstances, Africa has received little attention. Even though Seoul has shown its willingness to extend its outreach in the continent, scholars such as Yoo and Seol (2015: 219) question whether South Korea has a long term vision of engagement and a genuine set of policies for Africa.

Despite increased efforts to establish research institutes and think tanks, South Korea has lagged behind its neighbours, China and Japan, which have explored and implemented various areas of cooperation with various actors in the African continent. This is due to lack of resources (experts and professionals/financial) and the interest of the South Korean public. A prominent example that demonstrates South Korea's limited capacity and its operational challenges when engaging with Africa is the postponement of the fourth Korea-Africa Forum, which was supposed to be held in 2014. This prompted speculation regarding South Korea's commitment among observers. Under the circumstances, this gives rise to questions regarding Seoul's ability to manage its relationship with Africa. Commentators argue that there was a difficulty coordinating schedules between the African Union (AU) and the South Korean government regarding the Forum (Darracq and Neville, 2014). Another source (Interview, 4 November 2015) points out that South Korea's lack of experience dealing with African actors negatively affected finding a reliable partner 


\section{AFRICAN \\ EAST-ASIAN \\ AFFAIRS

with whom to materialise the Forum. Despite it being a decade since Seoul resumed engagement, it seems that the South Korea-African relationship is still far from mature.

In recent years, more room has been made in the foreign policy arena for various actors, such as civil society, to play a role in the policy-making process (Robinson, 1999). Despite this, in the case of South Korea, the current level of engagement of civil society and its capacity to influence the government's foreign policy towards Africa tends to be marginal, despite a growing interest in engagement in various activities in Africa. A narrow circle of political economic elites still retains the ultimate decision-making power (Holsti, 1970). Resultantly, high-level government officials play a central role in the foreign policy process with regard to Africa. Under the Roh and Lee administrations, resource or sales diplomacy which is mercantilist in nature, became the heart of foreign policy towards Africa, and political/economic elites ranging from high-level officials to businessmen shared this principle and were involved in promoting this idea. However, the successor, Park, does not share this enthusiasm (Kim and Gray, 2016). Overall, it seems that South Korea's interest in building and maintaining the relationship with African countries has lessened after Park took office, hence, scaling back on its earlier promotion of Africa in South Korea's foreign policy has become a reality.

\section{South Korea's national interests - rationales for engagement with Africa}

With regard to South Korea's burgeoning relationship with Africa, Heo and Roehrig (2014:149-150) identified its motivations and intertwined political-economic interests. This section to some extent overlaps with their analytical framework. However, a more detailed analysis on South Korea's aspiration for middle-powerism and resource diplomacy is provided. Furthermore, the diplomatic competition between the two Koreas on the continent, another aspect which has been largely overlooked, is examined to identify the rationales for South Korea's engagement with Africa. 


\section{The search for respect in the international community}

The expansion of South Korea's engagement with Africa is closely related to middle -powerism. Middle-powerism attracted the attention of South Korean scholars during the 1990s and soon after was translated into various policies (Robertson, 2013). The concept of middle power, a state that is neither a great power nor a small power, allows more space for countries like South Korea that recently gained "hard-power capacity, geopolitical and strategic locus, and leadership intentions within the international community" (Jordaan, 2003: 165). In the course of pursuing middlepower diplomacy, its "norm-based approach", rather than a power-based approach, created the opportunity for South Korea to seek its niche in its advances towards Africa (Hwang, 2014: 249). This concept rapidly gained legitimacy among the public in South Korea and the idea that South Korea should play a leading role in forming a bridge between the developed and developing countries gained momentum (Kim, 2012: 534). As South Korea's middle power diplomacy has evolved, the government has broadened its focus from regional issues to global agendas by participating in various multi-lateral platforms (Son, 2015). This has provided the framework for Seoul to include Africa in its diplomatic initiatives.

Since Roh's visit in 2006, South Korea's development cooperation with Africa has rapidly gained ground and led to South Korea tripling its development assistance. There were a number of events that were conducive to forging the relationship with Africa, instilling the nation with the sense that it should play a prominent role as a middle power at both the regional and global level. In 2006, the former foreign minister, Ban Ki-moon, became Secretary-General of the United Nations (UN). Since 2010, South Korea has become a member of the Organisation for Economic Cooperation and Development/Development Assistance Committee (OECD/DAC).

Following Roh's tour, various multi-lateral platforms, such as the Korea-Africa Forum and the Korea-Africa Economic Cooperation (KOAFEC), were established to strengthen co-operation with Africa and support its development. ${ }^{3}$ The Korea-Africa Forum is one of the key elements of South Korea's Africa policy, institutionalising the relationship. In 2006, the first forum was hosted by the Ministry of Foreign 


\section{AFRICAN \\ EAST-ASIAN \\ AFFAIRS

Affairs (MOFA, 2016). ${ }^{4}$ Compared to China's FOCAC and Japan's Tokyo International Conference of Africa's Development (TICAD), the Korea-Africa Forum is smaller in the number of participants and their level in government, mostly ministerial or director-general level instead of head of state level. Despite this limitation, South Korea has maintained working-level relations with partners. One of the interviewees argues that the South Korean side focuses on the "manageability" of the relationship by having a small number of African states instead of competing with China or Japan (Interview, 5 June 2014). Nevertheless, problems arose within the South Korean government such as a lack of interaction or coordination, and the sharing of information between ministries, thus, synergy effects are limited (Interview, 5 June 2014).

Even though South Korea has increasingly supported various agendas in Africa such as contributing to peace-keeping missions and humanitarian relief efforts on the continent (MOFA, 2016), there has been criticism that South Korea's intertwined economic interests underpin its approach towards Africa. South Korea's development assistance is viewed as a "political vehicle" (Kim and Gray, 2016; Kalinowski and Cho, 2012). Scholars such as Watson (2011: 60) argue that South Korea's ODA, for example, has been closely related to its economic interests targeting a few selected recipients through a high proportion of tied bi-lateral aid agreements with countries where South Korea's interests in natural resources and markets lie. This has largely overshadowed Seoul's development cooperation in Africa.

\section{Quest for natural resources}

Even though South Korea's aspiration to expand middle-powerism on the continent forms one pillar of its approach to Africa, its quest for natural resources remained at the centre of South Korea's relationship with Africa. South Korea's strategies towards Africa became explicitly mercantilist under President Lee Myung-bak, known for being the economic president. His personal experience as CEO of Hyundai Construction, one of the largest businesses in South Korea, appealed to the public during the presidential election. He emphasised entrepreneurial leadership and 
his top priority became exploring new markets and resources abroad to revitalise the domestic economy (Park, 2015).

The increasing level of geo-political tension in the Middle East made South Korea look to other regions for energy supply. South Korea realised the urgency and importance of energy security during the commodity shortage of 1972-1973 and the oil shock of 1973-1974. Nevertheless, energy diplomacy was not treated as important because global oil prices were steadily declining at that time. However, energy security has become the official guiding principle of South Korea's foreign policy in the early 2000s. The National Energy Advisory Committee was established in 2006 to prepare a mid- to long-term energy policy. In 2006, the Parliament enacted the Energy Act, which aims to attract new investments and promote development of the energy sector (National Law Information Centre, 2016). Resource diplomacy appeared to bestow strategic advantages in the quest to forge a relationship with Africa (Heo and Roehrig, 2014). Various South Korean government ministries have been strengthening relationships with countries in Africa. Meetings involving high level officials aimed at securing energy resources have become institutionalised since the mid-2000s (MOTIE, 2016). ${ }^{5}$

Lee accelerated reaching out to new partners, and resource diplomacy became a core principle of his foreign policy (Snyder, 2009). One of the prominent examples is that the Ministry of Foreign Affairs and Trade embarked on a project to build an "energy cooperation belt" across Central Asia, Africa and Latin America, with the assignment of South Korean energy cooperation advisors at 22 overseas diplomatic missions in these regions (MOFA, 2009). His resource diplomacy was spearheaded by a number of state-owned enterprises (SOEs) (Darracq and Neville, 2014), with the Korea National Oil Corporation (KNOC), Korea Gas Corporation (KOGAS) and the Korea Resources Corporation (KORES) being at the forefront of the move. Under the Lee administration, South Korea's overseas investment in the energy sector reached KRW 27 trillion (Korea Herald, 4 April 2015).

In 2015, Park also visited a number of resource-rich countries in the Middle East, such as Kuwait, Saudi Arabia, United Arab Emirates (UAE) and Qatar, which shows 


\section{AFRICAN \\ EAST-ASIAN \\ AFFAIRS

that her foreign policy priority is the same as that of predecessors. However, during the visit, her main focus areas seemed to shift to so-called "soft" areas such as IT, healthcare and tourism (Presidency, 2015). This trend could also be seen during her visit to South American countries such as Columbia, Peru, Chile and Brazil in 2015 (Presidency, 2015). This new direction of cooperation was also evident during her African tour. During Park's visits to Ethiopia, Uganda and Kenya in 2016, Seoul announced that it will provide education and vocational training for a total of 6,000 Africans during the next five years (Presidency, 2016). Park's initiative, "Korea Aid" comprises projects providing mobile food and basic healthcare services in rural areas. It also aims to spread aspects of Korean culture such as Korean food, music and films. However, a closer look reveals that only a handful of vehicles are involved in this project. It is thus possible to say that although "Korea Aid" could be an overarching framework guiding the future of South Korea-African relations, promoting the well-being of the recipient community and spreading Korean soft power, the practicality and usefulness of the approach is still questioned. Another criticism levelled against Park's African tour and "Korea Aid" was that there was no prior consultation with stakeholders and experts in South Korea as well as the three African countries (ODA Watch, 2016). Civil society in South Korea has expressed concerns that this initiative is tokenism rather than involving genuine transfer of knowledge and resources, and will not contribute to the welfare of local communities. It might even undermine South Korea's other efforts (Pressian, 30 May 2016). While South Korea and Africa relations have continued through highlevel meetings, the actual efforts have faced challenges regarding a lack of meaningful content on the ground.

\section{Competition between the two Koreas}

The African continent has long been a battlefield for competing ideologies (the United States versus the Soviet Union) or diplomatic recognition (the People's Republic of China versus the Republic of China). Likewise, the two Koreas' competition for diplomatic recognition has expanded to the continent. North Korea seemed to have won over its allies in Africa by the 1980s, at which time the country had 40 diplomatic relationships in Africa, outpacing South Korea which maintained 
only 28 diplomatic allies on the continent (Yoo and Seol, 2015: 232). While experiencing democratisation and globalisation from the 1990s onwards, South Korea started expanding and diversifying partnerships with Pacific island countries and South America. The demise of communism reversed the dynamics of the relationships, creating the opportunity for South Korea to engage with former communist nations in East Europe. The government also started looking for a way to fill the diplomatic void left in the African continent over the past few decades (MOFA, 2009). In contrast, North Korea seems to have lost its influence on the continent. The current involvement of its diplomatic missions in illicit activities such as the arms trade, military training and wildlife trafficking has marred its reputation (News24, 23 December 2015). Based on dismal levels of development, North Korea's Juche ideology, promoting autonomy or self-reliance, has failed to attract new audiences in Africa, except for a handful of allies such as Zimbabwe (Armstrong, 2009).

Nevertheless, the diplomatic competition for engagement with the continent of Africa seems to linger on. Following the recent visit by Park to the Ugandan President, Yoweri Museveni, the South Korean government announced that Uganda, one of North Korea's closest allies, would sever its relationship with North Korea (The Wall Street Journal, 30 May 2016). The South Korean government's announcement was immediately followed by criticism from the Ugandan government, which stated that South Korea made this public disclosure unilaterally (Mail \& Guardian, 29 May 2016). Despite this diplomatic setback with Uganda, South Korea has vigorously expanded its outreach to include North Korea's allies. In fact, following the African visit, the South Korean foreign minister visited Cuba, one of North Korea's closest friends for decades, where he proceeded to normalise diplomatic relations with the socialist island state (Yonhap News Agency, 5 June 2016). At the same time, North Korea has continued to counter South Korea's diplomatic expansion in Africa. In May, the President of the Presidium of the Supreme People's Assembly of North Korea - the official head of state, Kim Youngnam-attended President Obiang Nguema's inaugural ceremony in Equatorial Guinea. During his visit, Kim Young-nam met with African leaders from Chad, 


\section{AFRICAN \\ EAST-ASIAN \\ AFFAIRS

Gabon, Central Africa, Congo, Mali, Burundi and the former president of Mozambique (Yonhap News Agency, 23 May 2016). In April 2016, Angola and North Korea discussed cooperation on public security and North Korea agreed to send medical doctors to Angola (NK News, 8 April 2016). ${ }^{6}$ The prolonged competition between the two Koreas might lead to waste of resources which could have been re-directed to other development projects.

\section{New challenges for maturing the relationship with Africa}

In the case of South Korea's foreign policy towards Africa, while pursuing the primacy of national interests, each South Korean administration has taken a different approach towards Africa. Under Park, it has especially faced an inexorable, gradual decline which inhibits the maturing of the relationship.

South Korea's foreign policy with respect to Africa is faced with multiple obstacles. While the foreign policy of small states is susceptible to changes in international relations, the domestic political environment, which also helps to form foreign policy, plays a pivotal role in shaping governmental action (Evans, 2009). In this respect, domestic politics has a significant impact on foreign policy choices and their outcomes (Fearon, 1998). North Korea's security challenges have led to South Korea' diverting its focus away from the African continent; and the mounting criticism of resource diplomacy under President Lee has forced Park to find a way to differentiate herself from her predecessor. In this process, Africa has again been placed at the periphery of South Korea's foreign policy.

\section{Deteriorating security environment on the Korean peninsula}

South Korea's foreign relations have been predominantly shaped by its conflict with North Korea and on its geo-political relations with the major powers surrounding the peninsula-namely, the US, China, Japan and Russia. South Korea's attitude towards the North has been to alternatively adopt hard and soft-line stances along with the changes in political leadership. Roh's foreign policy towards North Korea highlighted engaging the North and initiating dialogue. In the same vein, Roh prioritised "peaceful co-existence" in the Korean peninsula through economic 
cooperation with Pyongyang (Kim, 2006). In this context, his so-called "Participatory Government" aimed to play the role of balance-keeper in Northeast Asia, and sought much more independence than previous administrations with respect to relationships with South Korea's traditional allies, including the US. Since the outbreak of the Korean War, South Korea has tried to keep the wartime alliances with the US intact in order to deter North Korean aggression. However, Roh sought a more independent and assertive position (The Diplomat, 13 June 2015). This shift was contested within the country, especially by the Conservative opposition. His autonomous stance towards the US put the bi-lateral relationship under strain (Ryu, 2013). Roh's approach especially created a rift with Bush's "axis of evil" hard-line stance against North Korea (Kim, 2006). ${ }^{7}$

Lee Myung-bak from the Conservative Party took a much more hard line approach towards North Korea. Even though Lee announced "Vision 3,000", which was pledged to help North Korea raise its gross domestic product (GDP) per capita to at least US\$ 3,000 within a decade, and North Korean denuclearisation as decided during the Six-Party Talks, his policy turned out to be a "failure" since it was based on the "prediction of North Korea's collapse" and "the unreality of the Reunification" (Paik, 2009). Even though Lee envisioned a "Global Korea" and had ambitions for a higher international profile, his aspirations were constrained by issues of security on the Korean peninsula (Snyder, 2009).

Since Kim Jong-il's death in December 2011, North Korea under Kim Jong-un has posed an increasing military threat, which has forced Park Geun Hye's conservative administration to shift its focus and priority to security. Since Park assumed the presidency in 2013, she has focused on building trust, translated into Trustpolitik and peace in Northeast Asia. Nevertheless, in March 2013, North Korea cut the channel of communication, warning of nuclear attack targeting the US and the South in response to UN sanctions in February (Daily News, 27 March 2013). In February 2016, Kaesong Industrial Complex, a landmark project involving inter-Korean cooperation, finally shut down due to the nuclear test and missile launch by North Korea. In this context, the efforts involving denuclearisation have been virtually stopped. Considering that Seoul's single most important foreign policy priority is 


\section{AFRICAN \\ EAST-ASIAN \\ AFFAIRS

unification of the peninsular, this prolonged, deteriorating, confrontational SouthNorth relationship has made South Korea's foreign policy-makers pursue a narrow range of foreign policy interests. Consequently, commitment to a certain set of foreign policy goals with respect to the developing world has ceased.

\section{Resource diplomacy and the loss of its legitimacy}

While Seoul has struggled with relations with security stakeholders, internal constraints associated with the previous administration's resource diplomacy have significantly affected both domestic discourse on the relationship with Africa and a shift in South Korea's relationship away from Africa. After his term of office, Lee's two major projects that mobilised SOEs were subjected to mounting criticism. The public works, Four-Rivers Project (wherein the four largest rivers were turned into reservoirs by building 16 small dams under his National Green Growth Policy), had come under strong criticism from its initiation (Asia Times, 02 December 2011). ${ }^{8}$ Lee's other signature project during his term, resources diplomacy, which is directly related to the African continent, also faced criticism due to its "poor preparation and hasty implementation" (Korea Times, 15 June 2016). Involvement of major SOEs such as KNOC, KORES, KEPCO and KOGAS resulted in "project failures, asset losses and the aggravation of financial solvency" according to the National Assembly audit of state affairs (ibid.).

The Lee Myung-bak administration sought to strengthen diplomatic approaches to African governments highlighting a sense of crisis amid the increasing international competition to secure energy and resources, a move that was intensified by the strong presence of China in Africa in particular. Lee's brother, Lee Sang-deuk, a politician, played the role of "special envoy for resource diplomacy" (The Hankyoreh, 25 January 2015). He and Park Young-joon, former Knowledge Economy Deputy Minister and a close associate of Lee Myung-bak, spearheaded exploring new partners in resource-rich countries. ${ }^{9}$ Lee Sang-deuk was involved in Namibia's uranium extraction (The Korea Herald, 06 February 2012). Park Youngjoon supported the mining of diamonds in Cameroon, and a public housing project in Ghana. Kim Eun-seok, the ministry's ambassador for energy and resources who was 
later dismissed from Foreign Affairs and Trade due to the so called MOFAT Diamond Scandal, visited Ethiopia, Uganda, Cameroon and Sudan to seal business deals (Seoul News, 18 January 2012). After the termination of Lee's term in February 2013, the promises of overseas resource development turned out to be largely illusory. A total of 96 Memorandums of Understanding (MoUs) for natural resources across the world were signed under the Lee administration, but "only 16 MoUs have become legally binding contracts, while the government suffered huge losses by investing in a heavily debt-ridden energy company" (The Korea Times, 05 May 2016). Under Lee, more than US\$ 28.5 billion was spent on SOEs' overseas resource development projects alone. As of late 2014, the losses were calculated at around US\$ 3.7 billion. A major media investigation reveals that "many of the projects are now positioned for withdrawal, sale, or downsizing, and with growing financial costs, the losses appear likely to continue growing" (The Hankyoreh, 25 January 2015).

At first glance, Park's foreign policy seems similar to those of her predecessor, Lee. When looking at the Eurasia Initiative, an "integrated system of transport, energy, and trade networks across the vast Eurasian continent" (Asan Institute, 2015), it is clear that some of Park's foreign policy priorities are also in line with resource diplomacy (ibid.). However, in 2013, Foreign Minister Yun Byung-se stated that "the government will change its approach from 'resource' to 'market' and 'aid' to 'trade and investment"' (MOFA, 2013). At the end of 2014 a special investigation team was set up to probe Lee's resource diplomacy. The investigation of resource diplomacy has revealed that a series of projects were marred by waste, mismanagement and corruption and this has been a popular topic in the mainstream media and public discussion. Public opinion and the media have asked for more accountability with regard to the government's overseas activities including state visits. In 2016, President Park laid out her key public sector reform plans, targeting SOEs, in order to deliver greater public sector productivity since "the industry's monopolistic structure has triggered numerous problems such as poor management... and snowballing debt" (Arirang News, 15 June 2016). The series of scandals has generated negative perceptions of the engagement with Africa among the public. 


\section{AFRICAN \\ EAST-ASIAN \\ AFFAIRS

During a survey conducted by a non-governmental organisation (NGO), People's Solidarity for Participatory Democracy, 74 per cent of the respondents criticised Lee's resource diplomacy and demanded further investigation of Lee himself (Civil Servants U Newspapers, 14 November 2014). The Park administration has started differentiating itself from the previous administration. This has further affected the continuity of the relationship between South Korea and its potential partners in Africa.

\section{Conclusion}

Political and economic self-interest retains its primacy in South Korea's foreign policy towards Africa. South Korea has aspirations to gain international recognition and this has been translated into a discourse on expanding its presence on the continent. Resultantly, there have been some achievements, such as the expansion of the scale and scope of aid and the establishment of the Korea-Africa Forum within the Korean Initiative for the development of Africa. Despite this progress, there has been a lack of a coherent approach and of continuity from the South Korean side which hampers the long term relationships.

Whilst analytical frameworks focusing on South Korea's aspiration to expand its middle-powerism on the continent and its resource-seeking behaviour became dominant in academic discourse on South Korea's foreign policy towards Africa, the focus in this article is on other domestic constraints that have negatively affected South Korea's foreign policy choices. The deterioration of the inter-Korean relations has led to South Korea once again giving priority to its relationship with security stakeholders such as the US and China. In this context, Africa has again been placed at the periphery of foreign policy. At the same time, resource diplomacy faced growing criticism from the public and has lost its legitimacy as a basis for engagement with the continent. These two processes have had an impact on the reorientation of South Korea's foreign policy towards Africa. 
AFFAIRS

\section{Endnotes}

1. Before Roh's African tour, Chun Doo-hwan (1980-1988) was the only South Korean president who had visited African countries, including Kenya, Nigeria, Gabon and Senegal in 1982 (Kim, 2013: 54).

2. Other emerging powers have actively promoted their presence by utilising similar multi-lateral mechanisms such as the Forum for China and Africa Cooperation (FOCAC) and the India-Africa Forum Summit amongst others, thereby strengthening their links with their African partners. China's FOCAC has become a prominent mechanism to promote development cooperation between China and Africa. Its latest meeting, a summit in fact, was held in South Africa in December 2015. President Xi Jinping's attendance and pledge to provide US\$ 60 billion assistance to Africa for the next three years signals China's continuous commitment to the continent. In addition to FOCAC, China is part of BRICS, another global grouping, which aims to represent the voice of the Global South and to rectify the unbalanced international system largely dominated by the Global North. India is another emerging power that has actively engaged with Africa through historical linkages such as migration networks and non-alignment movements. The India-Africa Forum Summit is the official platform for the African-Indian relations.

3. KOAFEC is another mechanism that South Korea has held with Africa focusing on economic cooperation. The conference takes place every two years and it involves South Korea's Finance and Strategy Ministry and the African Development Bank (AfDB). Participants increased from 15 countries in 2006, 22 in 2008, 35 in 2010. At the 2016 KOAFEC, the South Korean government announced its plans to offer US\$ 10 billion cooperation package in Africa over the next two years.

4. At the second forum in 2009, South Korea emphasised its intention to strengthen South Korea's partnership with Africa through the Seoul Declaration. The country reaffirmed that it will support Africa in eradicating poverty and achieving sustainable development as well as to promote the 


\section{AFRICAN \\ EAST-ASIAN \\ AFFAIRS

prosperity of African countries and South Korea. It was announced that South Korea's ODA would be doubled by 2012, ten cooperation areas were introduced including: Poverty Eradication and Sustainable Development, Agriculture and Rural Development, Education and Vocational Training, Public Health Services, Trade and Investment, Information Communication Technology (ICT), Environment and Climate Change, Regional and International Cooperation, Cooperation with the Private Sector and Civil Society and Effectiveness of Partnership. It was also announced that 5,000 Africans would be invited for training and that the government would send 1,000 volunteers.

5. The Ministry of Trade, Industry and Energy (MOTIE) has encouraged enterprises to invest in the continent by holding the Korea Africa Industry Cooperation Forum (KOAFIC) every year since 2008 (MOTIE, 2016). The Korea Trade-Investment Promotion Agency (KOTRA) is another main agency tasked with exploring markets in Africa.

6. Historically, diplomatic competition, for example "dollar diplomacy", that is, Taiwan's strategy vis á vis China in order to maintain diplomatic allies, has perpetuated corruption in Africa as political elites have access to aid to strengthen their own positions (Taylor, 2006).

7. Despite the improvement of inter-Korean relations, including economic cooperation such as the Kaesong Industrial Complex, the Roh administration was faced with North Korea's continuous nuclear tests and missile programme. The sinking of the South Korean navy ship, the Cheonan, during an attack from the North in 2010, exacerbated inter-Korean relations.

8. Due to its high environmental impact, the project was strongly challenged from opposition parties and progressive civil society groups. The government invested US\$ 18 billion on the project, amounting to roughly two per cent of South Korea's GDP. A few years later, it turned out that the four major rivers (Han, Nakdong, Geum, and Yeongsan Rivers) have been ecologically and geographically transformed by construction. 
AFFAIRS

9. Lee Sang-deuk was also heavily involved in activities concerned with extracting lithium in Bolivia. It was revealed that a number of his visits to Bolivia in particular became linked to South Korea's ODA channel to Bolivia, a lower-middle-income country rather than other least developed countries in the region (The Korea Herald, 06 February 2012). 
AFRICAN

EAST-ASIAN

AFFAIRS

\section{Bibliography}

Armstrong, C. 2009. Juche and North Korea's Global Aspirations. North Korea International Documentation Project Working Paper Series. [Online]. Available: https://www.wilsoncenter.org/sites/default/files/NKIDP_WP_1.pdf [Accessed: 8 September 2016].

Arirang News. 2016. Korean government to push for large-scale public sector reform. [Online]. Available: http://www.arirang.com/News/News_View.asp? nSeq $=192293$ [Accessed: 8 September 2016].

Asan Institute for Policy Studies. 2014. 세일즈 외교로 기억된 박근혜 정부의 외 교 첫해. Asan Institute for Policy Studies. [Online]. Available: http:// asaninst.org/contents/\%EC\%84\%B8\%EC\%9D\%BC\%EC\%A6\%88-\%EC\% 99\%B8\%ЕA\%B5\%90\%ЕB\%A1\%9C-\%ЕA\%B8\%B0\%ЕC\%96\%В5\%ЕB\% 90\%9C-\%ЕB\%B0\%95\%ЕA\%B7\%BC\%ED\%98\%9C-\%ЕC\%А0\%95\%ЕВ\% B6\%80\%EC\%9D\%98-\%EC\%99\%B8\%EA\%B5\%90-\%EC\%B2\%AB\%ED\% 95\%B4-2/ [Accessed: 8 September 2016].

Asia Times. 2011. Korea's rivers take brunt of shoveling politics. [Online]. Available: http://www.atimes.com/atimes/Korea/ML02Dg01.html [Accessed: 8 September 2016].

Callahan, P. 2004. Logics of American Foreign Policy: Theories of America's World Role. New York: Pearson Longman.

Carder, K. 2005. Korea's energy insecurities : comparative and regional perspectives. Korea Economic Institute of America. [Online]. Available: http:// www.keia.org/sites/default/files/publications/05Calder.pdf [Accessed: 8 September 2016].

Cho. H. 2010. 한국의 대 아프리카 외교의 성공조건. 정세와 정책 (세종연구 소). 2:8-11. 
AFRICAN

EAST-ASIAN

AFFAIRS

Choi, K. et al. 2014. Evaluating President Park Geun-Hye's Foreign Policy in its 1st Year. Asan Institute for Policy Studies. [Online]. Available: http:// en.asaninst.org/contents/evaluating-president-park-geun-hyes-foreign-policy-in -its-1st-year/ [Accessed: 19 September 2016].

Civil Servants U Newspapers. 2014. 국민 74\%, MB 자원외교 국정조사 필요. [Online]. Available: http://www.upublic.co.kr/news/articleView.html? idxno=2098 [Accessed: 27 October 2016].

Daily Korea. 2016. 박근혜 대통령 중동 순방 숨겨진 비밀? [Online]. Available: http://aily.hankooki.com/lpage/politics/201503/ dh20150307104242137430.htm [Accessed: 8 September 2016].

Daily News. 2013. North Korea to cut off all communication with South. [Online]. Available: http://www.nydailynews.com/news/world/north-korea-cut-channelssouth-article-1.1300489 [Accessed: 8 September 2016].

Darracq, V. and Neville, D., 2014. South Korea's Engagement in Sub-Saharan Africa: Fortune, Fuel and Frontier Markets. Chatham House. [Online]. Available: https://www.chathamhouse.org/sites/files/chathamhouse/field/ field_document/20141027SouthKoreaAfricaDarracqNeville.pdf [Accessed: 8 September 2016].

Evans, N. 2009. What is the relationship between domestic and foreign policy? [Online]. Available: http://www.e-ir.info/2009/05/16/what-is-the-relationshipbetween-domestic-and-foreign-policy-should-they-even-be-distinguished/ [Accessed: 8 September 2016].

Fearon, J. 1998. Domestic Politics, Foreign Policy, and Theories of International Relations, Annual Review of Political Science, 1(1):289-313.

Hermanns, H. 2013. National Role Conceptions in the 'Global Korea' Foreign Policy Strategy. The Korean Journal of International Studies, 11(1):55-82.

Heo, U., and Roehrig, T. 2014. South Korea's Rise: Economic Development, Power 
AFRICAN

EAST-ASIAN

AFFAIRS

and Foreign Relations. Cambridge University Press.

Hey, K. 2003. Small States in World Politics: Explaining Foreign Policy Behaviour. Lynne Rienner Publishers.

Holsti, K. 1970. National Role Conceptions in the Study of Foreign Policy. International Studies Quarterly, 14(3):233-309.

Hwang, K. 2014. Korea's Soft Power as an Alternative Approach to Africa in Development Cooperation. African and Asian Studies, 13(3):249-271.

Jordaan, E., 2003. The concept of a middle power in international relations: distinguishing between emerging and traditional middle powers. Politikon, 30 (1):165-181.

Jung, S. 2008. Political Economy of Oil and Korean Resources Diplomacy to Middle East. Journal of East and West Studies, 20(2):63-89.

Kalinowski, T., and Cho, H. 2012. Korea's Search for a Global Role between Hard Economic Interests and Soft Power. European Journal of Development Research, 24(2):242-260.

Kim, S., and Gray, K. 2016. Overseas Development Aid as Spatial Fix? Examining South Korea's Africa policy. Third World Quarterly, 37(4):649-664.

Kim, E., Kim, P., and Kim J. 2013. From Development to Development Cooperation: Foreign Aid, Country Ownership, and the Developmental State in South Korea. The Pacific Review, 26(3):313 -336

Kim, H. 2006. South-North Korean Relations under the Roh Government. International Journal of Korean Studies, 5(1):37-59.

Kim, S. 2016. South Korea's Middle-Power Diplomacy: Changes and Challenges. Chatham House Research Report. London: Chatham House. [Online]. Available: $\quad$ https://www.chathamhouse.org/sites/files/chathamhouse/ publications/research/2016-06-22-south-korea-middle-power-kim.pdf [Accessed: 16 September 2016]. 
AFFAIRS

Kim, S. 2013. Korea in Africa: a missing piece of the puzzle?. LSE Ideas: Emerging Powers in Africa. [Online]. Available: http://www.lse.ac.uk/IDEAS/ [Accessed: 16 September 2016].

Kim, T. 2012. Paradigm Shift in Diplomacy: A Conceptual Model for Korea's "New Public Diplomacy". Korea Observer, 43(4):527-555.

Kim, Y. 2016. Commentary: The two Koreas and Africa in the 21st century. Stellenbosch: Centre for Chinese Studies.

Lee, H. 1999. Korea' s Foreign Policy toward Africa: Re-estimation and New Direction. Korean Political Science Review, 33(3): 371-390.

Lee, H. unknown. Korea's Policies on Africa: Development of Energy and Resources Diplomacy. Ilmin International Relations Institute. [Online]. Available: http://www.koreafocus.or.kr/design2/layout/content_print.asp? group_id=103809 [Accessed: 8 September 2016].

Mail \&Guardian. 2016 Diplomatic 'mischief' as Uganda angered by visiting South Korea president's claim of end to ties with N. Korea. [Online]. Available: http://mgafrica.com/article/2016-05-29-diplomatic-mischief-uganda-angeredby-visiting-south-korea-presidents-claim-that-it-has-cut-military-ties-withnkorea [Accessed: 8 September 2016].

MOFA. 2009. 한국외교 60년. [Online]. Available: http://www.mofa.go.kr/state/ publication/history60/20091230/10480_file_2009\%20dip60_3.pdf [Accessed: 8 September 2016].

MOTIE. 2016. Press Releases. [Online]. Available: http://english.motie.go.kr/? cat $=26$ [Accessed: 8 September 2016].

National Law Information Centre. 2016. Energy Law. [Online]. Available: http:// www.law.go.kr/lsInfoP.do?1siSeq=142354\&efYd=20131031\#0000 [Accessed: 8 September 2016].

News24. 2015. North Korean diplomat expelled from SA for rhino horn trafficking. 


\section{AFRICAN \\ EAST-ASIAN \\ AFFAIRS

[Online]. Available: http://www.news24.com/SouthAfrica/News/exclusivenorth-korean-diplomat-expelled-from-sa-for-rhino-horn-trafficking-20151223 [Accessed: 8 September 2016].

NK News. 2016. Angola discusses public security cooperation with North Korea. [Online]. Available: https://www.nknews.org/2016/04/angola-discusses-publicsecurity-cooperation-with-north-korea /[Accessed: 8 September 2016].

ODA Korea. 2016. Results and Data: Africa. [Online]. Available: http:// www.odakorea.go.kr/eng.result.RegionCountry_Africa.do [Accessed: 8 September 2016].

ODA Watch. 2016. 코리아에이드(Korea Aid)는 진정 한국 원조인가? [Online]. Available: http://webcache.googleusercontent.com/search? $\mathrm{q}=$ cache:rt9IJsti0zUJ:www.odawatch.net/\%3Fmodule $\% 3 \mathrm{Dfile} \% 26 \mathrm{act} \%$ 3DprocFileDownload\%26file_srl\%3D470058\%26sid\% 3Dba8881c27b26fe576436f79633e7ffa4+\&cd=15\&hl=en\&ct=clnk\&gl=za [Accessed: 28 October 2016].

Paik, H. 2009. The Lee Myung-bak Government's North Korea Policy: Assessment and Implications. The Sejong Institute.

Park, J. 2015. Korea's Linkage Strategy between FTA Hub Policy and Middle Power Leadership in Regional Economic Integration. Asia Europe Journal, 13(4):379394.

Presidency. 2015. Summit Diplomacy. http://www1.president.go.kr/news/ overseasTrip/2015/trip2015.php [Accessed: 8 September 2016].

Pressian. 2016. 박근혜가 꽂힌 '코리아 에이드', 정체는? [Online]. Available: http://www.pressian.com/news/article.html?no=137211 [Accessed: 8 September 2016].

Robertson, J. 2013. Middle-powerism \& Continuity in South Korean Foreign Policy. The Diplomat. [Online]. Available: http://thediplomat.com/2013/05/ 
middlepowerism-continuity-in-south-korean-foreign-policy/

[Accessed:8 September 2016].

Robinson, P. 1999. The CNN effect: can the news media drive foreign policy?. Review of international studies, 25(2):301-309.

Ryu, Y. 2013. Does Political Generation Matter for Foreign Policy? South Korea's Foreign Policy Changes, 2003 to 2007. The Korean Journal of International Studies, 11(1):113-141.

Seoul News. 2012. 보도자료로 시작된 CNK 의혹 어디까지 가나. [Online]. Available: http://seoul.co.kr/news/newsView.php? id=20120118800112\&spage=2827 [Accessed: 8 September 2016].

Snyder, S. 2009. Lee Myung-bak's Foreign Policy: A 250-Day Assessment. Korean Journal of Defense Analysis, 21(1):1-30.

Son, Y. 2015. Searching for a new identity: South Korea's middle power diplomacy. FRIDE Policy Brief. [Online]. Available: http://fride.org/descarga/ PB212_South_Korea_middle_power_diplomacy.pdf [Accessed: 8 September 2016].

Taylor, I. 2006. Taiwan's Foreign Policy and Africa: The Limitations of Dollar Diplomacy, Journal of Contemporary China, 11(30):125-140.

The Diplomat. 2015. The Evolution of the U.S-South Korea Alliance. [Online]. Available: http://thediplomat.com/2015/06/the-evolution-of-the-u-s-southkorea-alliance/ [Accessed: 26 October 2016].

The Hankyoreh. 2015. Resource diplomacy: \$4 billion in losses, and no one responsible. [Online]. Available: http://www.hani.co.kr/arti/english_edition/ e_national/675100.html [Accessed: 8 September 2016].

The Hankyoreh. 2015. The full travesty of Lee Myung-bak's 'resource diplomacy' money pit. [Online]. Available: http://english.hani.co.kr/arti/english_edition/ e_editorial/700357.html [Accessed: 8 September 2016]. 


\section{AFRICAN \\ EAST-ASIAN \\ AFFAIRS

The Hankyoreh. 2005. Leading the Way to Peace. [Online]. Available: http:// english.hani.co.kr/arti/english_edition/e_editorial/22940.html [Accessed: 8 September 2016].

The Korea Herald. 2015. 자원외교 투자금 90\% MB정부가 지출. [Online]. Available: http://biz.heraldcorp.com/view.php?ud=20150404000011 [Accessed: 8 September 2016].

The Korea Herald. 2012. Efficiency of 'resource diplomacy' hit after presidential aides' books. [Online]. Available: http://www.koreaherald.com/view.php? $\mathrm{ud}=20120205000238$ [Accessed: 8 September 2016].

The Korea Times. 2016. President's $\$ 45.6$ bil. business deal in Iran raises questions. [Online]. Available: http://koreatimes.co.kr/www/news/ biz/2016/05/602_204125.html [Accessed: 8 September 2016].

The Korea Times. 2016. Park belatedly tries to clean up predecessor's mess. [Online]. Available: $\mathrm{http}: / / \mathrm{www}$. koreatimes.co.kr/www/news/ biz/2016/06/123_207028.html [Accessed: 8 September 2016].

The Wall Street Journal. 2016. Victory for South Korea After North Loses Uganda as a Military Ally. [Online]. Available: http://www.wsj.com/articles/victory-for -south-korea-after-north-loses-uganda-as-a-military-ally-1464573717 [Accessed: 8 September 2016].

Watson, I. 2011. Global Korea: Foreign Aid and National Interests in an Age of Globalization, Contemporary Politics, 17(1): 53-69.

Yoo, H., and Seol, G. 2015. Paradigm Change of Korea's Foreign Policy towards Africa. Journal of Paradigm Studies, 30(2):217-245.

Yonhap News Agency. 2016. S. Korea, Cuba hold first foreign ministerial talks. [Online]. Available: http://english.yonhapnews.co.kr/ news/2016/06/06/0200000000AEN20160606003551315.html [Accessed: 8 September 2016]. 
AFFAIRS

Yonhap News Agency. 2016. N. Korea's Kim Yong-nam holds talks with Equatorial Guinea president. [Online]. Available: http://english.yonhapnews.co.kr/ northkorea/2016/05/23/0401000000AEN20160523005700315.html [Accessed: 8 September 2016].

Yun, Y. 2008. A Review of Korea's Energy Diplomacy in Terms of National Strategy. Journal of East and West Studies, 20(2):5-27. 